MATEC Web of Conferences 38, 02003 (2016)

DOI: $10.1051 /$ matecconf/20163802003

(C) Owned by the authors, published by EDP Sciences, 2016

\title{
Thermal comfort analysis of building assisted with Photo Voltaic Trombe wall
}

\author{
Kashif Irshad ${ }^{1, a}$, Khairul Habib ${ }^{1}$, Nagarajan Thirumalaiswamy ${ }^{1}$ and M.W.Kareem ${ }^{1}$ \\ ${ }^{1}$ Department of Mechanical Engineering, Universiti Teknologi PETRONAS, 32610 Bandar Seri Iskandar, Perak Darul Ridzuan, Malaysia
}

\begin{abstract}
Maintaining indoor climatic conditions of buildings compatible with the occupant comfort by consuming minimum energy, especially in a tropical climate becomes a challenging problem for researchers. This paper aims to investigate this problem by evaluating the effect of different kind of Photovoltaic Trombe wall system (PV-TW) on thermal comfort, energy consumption and $\mathrm{CO}_{2}$ emission. A detailed simulation model of a single room building integrated with PV-TW was modelled using TRNSYS software. Results show that 14-35\% PMV index and 26-38\% PPD index reduces as system shifted from SPV-TW to DGPV-TW as compared to normal buildings. Thermal comfort indexes (PMV and PPD) lie in the recommended range of ASHARE for both DPV-TW and DGPV-TW except for the few months when $\mathrm{RH} \%$, solar radiation intensity and ambient temperature were high. Moreover PVTW system significantly reduces energy consumption and $\mathrm{CO}_{2}$ emission of the building and also $2-4.8{ }^{\circ} \mathrm{C}$ of temperature differences between indoor and outdoor climate of building was examined.
\end{abstract}

\section{Introduction}

High economic growth in developed countries led to more dependence on high energy-consuming equipment for providing thermal comfort inside the buildings. Depending on previous studies buildings account for $40 \%$ of the total global energy consumption [1]. Within this, about $76 \%$ of energy is used only to provide heating and cooling, humidity control and comfort to the occupants [2]. According to BS EN ISO 7730 [3], thermal comfort is the mind condition to express satisfaction within the particular environment and depends on many factors. Factors include metabolic rate [For seating, light work etc. $\left.58 \mathrm{~W} / \mathrm{m}^{2}[3]\right]$, air temperature $\left[20-23.5^{\circ} \mathrm{C}\right.$ for winter and $23-26^{\circ} \mathrm{C}$ for summer], and relative air velocity [0.1 $\mathrm{m} / \mathrm{s}$ [3]]. Therefore, to reduce energy consumption without compromising with the comfort of the occupants, building integrated solar passive systems [4] are increasingly encouraged by national regulations. Solar passive systems heat, cools, ventilate or light buildings, without the need for electricity or mechanics [5]. Most typical solar passive systems used nowadays are Trombe walls [6]. Trombe-wall (TW) consist of thick thermal wall with a transparent outer glazing cover with an air duct in between [7]. By affixing photovoltaic (PV) cells on the transparent cover glazing a novel Trombe structure known as a (PV-TW) was designed by Ji et al. [8] that use solar energy not only for heating and cooling purposes, but also to harness electricity by photovoltaic cells. The PV-TW uses a PV panel that hinders the penetration of solar rays into the air space between the walls and glazing [9]. Therefore, the efficiency of the TW

\footnotetext{
a Corresponding author: alig.kashif@gmail.com
}

is enhanced in terms of cooling potential and thermal performance of Trombe wall was reduces up to $17 \%$ [9]. PV walls implemented in buildings located at three different cities of china were chosen to simulate the thermal performance and cooling load. It was found that a $\mathrm{PV}$ wall reduces $33-50 \%$ cooling load as compared to normal wall depending on the local weather conditions [10]. $\mathrm{He}$ and $\mathrm{Ji}$ [11] conducted simulation study on building integrated with $\mathrm{PV} / \mathrm{T}$ wall for summer season of Hong Kong (May-October) and found that the heat gain through a south-facing PV/T wall was $27 \mathrm{kWh} / \mathrm{m}^{2}$ less as compared to normal wall for same thickness. Yang et al [12] numerically investigated the effect of implementation of PV-wall on buildings and found that PV-wall structures significantly reduced heat gain in summer, thereby reduces cooling load of the building. Jinqing et al [13] numerically compared normal wall with south facing PV wall for summer climate of Hong Kong and found that PV wall reduces $51 \%$ of heat gain. Results also explain that PV wall not only reduces heat gain in morning but also reduces heat loss at nighttime. Energy consumption reduction of building equipped with PV wall for each square meter was $52.1 \mathrm{kWh}$. Wei et al [14] compare energy performance among see-through amorphous-silicon PV (photovoltaic) glazing and traditional glazing for different climatic condition of China. Results shows that the a-Si PV glazing reduces cooling energy consumption higher than the traditional glazing. PV electricity yield is relatively small, but the glazing still save $6.5 \%$ (low transmittance) and $4.9 \%$ (high transmittance) of total energy consumption on average. 
Although much literature concerning the thermal performance of a PV-TW has been published, there is limited research focusing on effect of various type of PVTW on thermal comfort of occupants. In this study thermal comfort analysis of a single zone building integrated with PV-TW was analyzed. Three different types of PV-TW system (i.e. Single glass PV-TW(SPVTW), evacuated double glass PV-TW(DPV-TW), doubleglass filled with argon PV-TW(DAPV-TW) were investigated. TRNSYS software was used for the simulation and performance of building was investigated based on the parameters i.e. Thermal comfort, room temperature and energy consumption

\section{Methodology}

The building performance was evaluated by means of building energy simulation program named Transient system simulation (TRNSYS) [15]. Various input data discussed below such as geometry, material characteristics of the building, metrological data, internal gains of building, air infiltrations, glazing type and ventilation rates were inserted to calculate the thermal comfort and temperature variation inside the building.

\subsection{Description of the test room.}

The simulation was conducted using the single-room house facility with PV-TW as shown in Figure 1 and 2, located in Universiti Teknologi PETRONAS (4²3'11"N and $100^{\circ} 58^{\prime} 47^{\prime \prime}$, Perak, Malaysia).

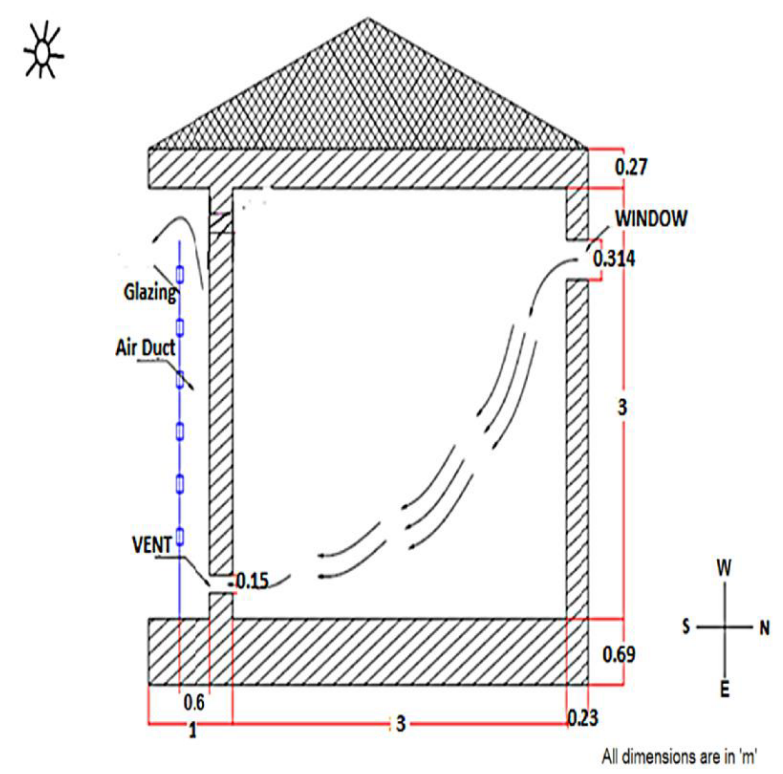

Figure 1. Schematic diagram of the test room with PV -TW

The construction details and thermo physical properties of building materials as shown in Table 1 of the existing single zone building are given according to previous studies [16].

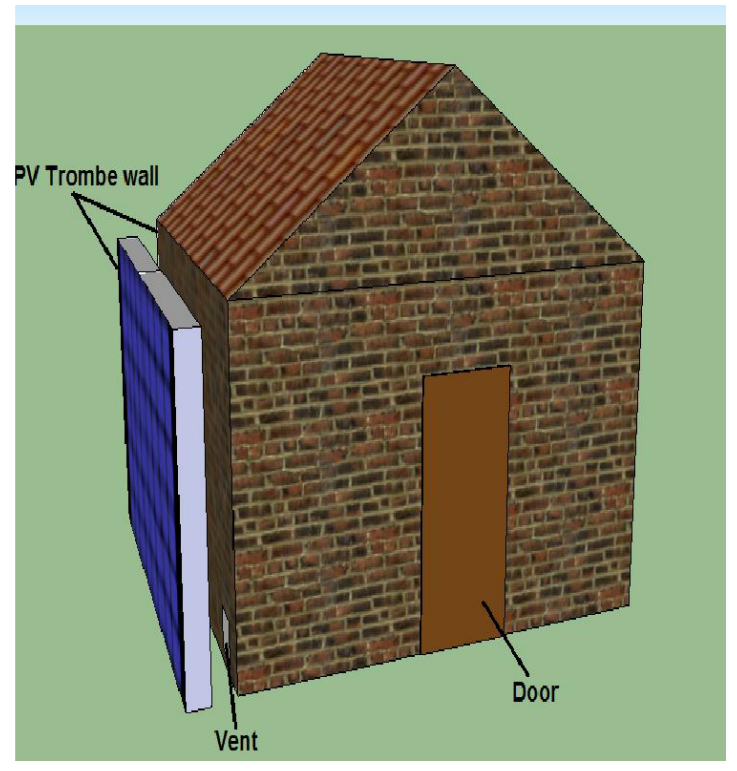

Figure 2. Diagram of the test room with PV -TW

Assumptions were made that the heat transfer across the walls and roof is unidirectional and occur along the thickness and is in quasi-steady state. The wall and roof structures were made of homogeneous material layers. The ambient, room air temperatures and solar intensity were assumed to be constant for $1 \mathrm{~h}$. Air change per hour was assumed to be constant and all thermal properties of building materials e.g. Thermal conductivity and specific heat were assumed constant.

1. The test room is of dimensions $3.0 \mathrm{~m}$ (width, $\mathrm{X}$ ) X 3.0 m (depth, Y) X 2.6 m (height, Z).

2. All exterior walls are three-layered with central layer composed of $22 \mathrm{~cm}$ thick brick wall and both the side walls are cement plastered. The plaster thickness is 1.5 $\mathrm{cm}$ for inside layer and $2.0 \mathrm{~cm}$ for the outside layer.

3. The roof is made up of roofing tiles of thickness 25 $\mathrm{cm}$.

4. The ground is made of first layer of cement mortar (10 $\mathrm{cm}$ thick), second layer of sand gravel (25 cm thick) and the last layer of soil or mud phuska (40 cm thick).

5. There is one window on the northwest wall. The height and width of the window are $0.314 \mathrm{~m}$ and $0.23 \mathrm{~m}$ respectively. The window is made of plywood of thickness $2.5 \mathrm{~cm}$. The windows open inside. Windows are not provided with overhangs.

6. A single steel door is on the southeast wall. The dimensions of the door are $2.134 \mathrm{~m}$ height and $0.914 \mathrm{~m}$ width. The door is made of $0.5 \mathrm{~cm}$ thick GI metal sheet. The door opens inside.

7. A vent of the size of $0.4 \mathrm{~m}(\mathrm{X}) \mathrm{X} 0.1 \mathrm{~m}(\mathrm{Z})$ is opened on the bottom of the absorber wall to connect the air flow between the air duct and the room. It is $0.15 \mathrm{~m}$ above the wall foundation. 
8. The PV-TW on the southern wall, which is located at $0.25 \mathrm{~m}$ from the western interior wall.

9. PV glass panel with an area of $2.6 \mathrm{~m}$ (height) X $0.84 \mathrm{~m}$ (width) and a thickness of $5 \mathrm{~mm}$, a matt black painted wall and an air duct with a depth of $0.18 \mathrm{~m}$ in between. The outer glazing of the PVTW is $5 \mathrm{~mm}$ thick glass, on the back of which is affixed with $5 \mathrm{~cm} \mathrm{X} 5 \mathrm{~cm}$ commercial multi-crystalline silicon PV cells with grid distribution. The PV glazing then appears of a matrix color of dark blue. The packing factor of PV cells on the glazing is about 0.334 .

Table 1. Thermo physical properties of building materials

\begin{tabular}{|c|c|c|c|}
\hline Material & $\begin{array}{c}\text { Density } \\
\left(\mathrm{kg} / \mathrm{m}^{3}\right)\end{array}$ & $\begin{array}{c}\text { Specific heat } \\
\left(\mathrm{kJ} \mathrm{kg}^{-1} \mathrm{~K}^{-1}\right)\end{array}$ & $\begin{array}{c}\text { Thermal } \\
\text { conductivity } \\
\left(\mathrm{W} \mathrm{m}^{-1} \mathrm{~K}^{-1}\right)\end{array}$ \\
\hline Brick tile & 1892 & 0.88 & 0.798 \\
\hline Mud brick & 1731 & 0.88 & 0.750 \\
\hline Mud phuska & 1622 & 0.88 & 0.519 \\
\hline Cement plaster & 1762 & 0.84 & 0.721 \\
\hline Cement mortar & 1648 & 0.92 & 0.719 \\
\hline Limestone tile & 2420 & 0.84 & 1.800 \\
\hline Sand grave & 2240 & 0.84 & 1.740 \\
\hline GI sheet & 7520 & 0.50 & 61.060 \\
\hline Plywood & 640 & 1.76 & 0.174 \\
\hline
\end{tabular}

\subsection{Internal gains}

Occupant's internal gains were assumed according to EN ISO 7730.2005[3] standard. For activities like seated, light work or typing $150 \mathrm{~W} /$ person (Sensible: $75 \mathrm{~W} /$ person and Latent: $75 \mathrm{~W} /$ person) heat was dissipated to the surroundings. Prototype room having facility of electric lighting with heat gain of $55 \mathrm{~W} / \mathrm{m}^{2}$ is supposed to accommodate two person.

\subsection{Energy consumption for electric lighting and equipment.}

According to CEN standard [17] room should have luminance level of $500 \mathrm{~lm} / \mathrm{m}^{2}$ and a lighting efficacy of $50 \mathrm{~lm} / \mathrm{W}$ [18]. Also room is equipped with basic equipment i.e. fan of $75 \mathrm{~W}$ and small Air Cooler of $250 \mathrm{~W}$ and PV-TW of capacity 500Wp [19].

\subsection{Time Schedules}

The schedules of occupancy of buildings are consider below:

Monday to Friday 08:00-07:00 with occupancy schedule: 08:00-14:00 with occupancy of 50\%.
15:00-08:00 with occupancy of $100 \%$

Saturday and Sunday 08:00-07:00 with occupancy schedule of $100 \%$.

\subsection{Infiltration and ventilation.}

Energy consumption for heating and cooling are interrelated with building's ventilation and infiltration. Ventilation is simulated by Type 2 module and ranges between 0.5 and $10 \mathrm{ACH}$ [20] while infiltration rate ranges between $0.2-2 \mathrm{ACH}[17]$.

\subsection{Indoor Environment}

Predicted Mean Vote (PMV) is used to evaluate indoor thermal comfort. According to CEN standard [16,17] annual indoor thermal comfort of a building is evaluated by calculating the time percentage of occupancy on hourly basis, and recommended range of PMV lies between $-0.5<$ PMV $<+0.5$.

\section{$2.7 \mathrm{CO}_{2}$ Emission mitigation}

The numerical calculation was carried out to estimate the amount of $\mathrm{CO}_{2}$ emission mitigated due to the existing different type of PV-TW system. The average intensity of $\mathrm{CO}_{2}$ discharge from coal thermal power plant in Malaysia is $1.21 \mathrm{~kg} / \mathrm{kWh}$ [21]. The total mitigation of $\mathrm{CO}_{2}$ emissions from the existing TE-AD system and conventional air conditioning systems for 30 years life can be calculated by using the equation as follows [22]:

$\mathrm{CO}_{2}$ emission mitigated $(\mathrm{kg} / \mathrm{life})=1.21(\mathrm{~kg} / \mathrm{kWh}) \times E$ (kWh/year) x $n$ (year)

\subsection{Simulation Process.}

Entire TRNSYS simulation modeling was defined by 11 modules (Types) as shown in Figure 3. Information flow diagram of TRNSYS model was shown in Figure 4. (Type 9a) data reader was installed to read the authentic weather data which was engendered as a .txt file. This data consists of the ambient temperature, irradiation and the relative sultriness that was accumulated from the weather station. The Daily Schedule utility programs (Type 517) was used to provide 24-hour schedule of the occupant of the building. The same schedule was repeated for every day of the simulation. (Type 574) was intended to provide typical latent and sensible loads for occupancy based on the activity level of the occupants. (Type 567-2) was installed in connection with (Type 36d) and then to (Type 56). (Type 567) was used to model a glazed solar collector which has the dual purpose of generating power from photovoltaic (PV) cells and transferring heat to an air inside an air duct passing beneath the absorbing PV surface. Input parameters i.e. inlet air temperature, air flow rate, ambient temperature, ambient solar radiation, incidence angle, PV efficiency, and glazing properties were inserted. (Type 36d) was set to model a thermal storage wall which is essentially a high capacitance solar collector directly coupled to the 
room. (Type 56) was intended to model a thermal behavior of a building having multiple thermal zones. A separate pre-processing program PREBID that can read and execute a file having all building information as discussed above was used. PREBID generates two files that are used by the Type 56 component during a TRNSYS simulation. (Type 25) is a printer component used to output (or print) culled system variables at designated intervals of time. (Type 642) models a fan that is utilized to vary the air flow velocity.

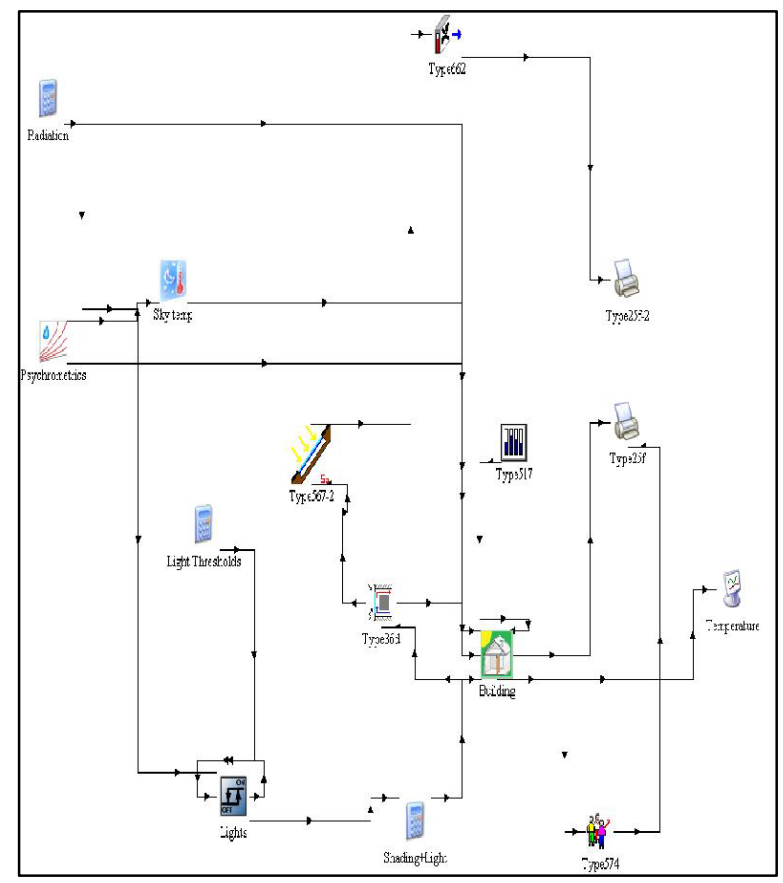

Figure 3. Assembly panel window.

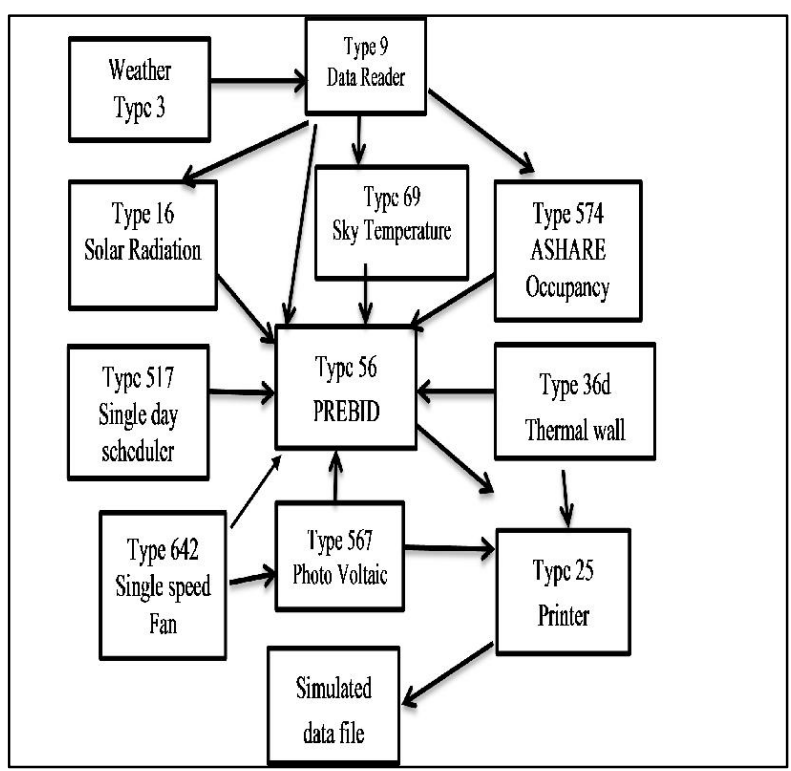

Figure 4. TRNSYS information flow diagram for PV-TW

\section{Results and Discussion}

In this section, we present the findings of implementation of different types of PV-TW system in the test room. Outdoor climatic condition of test room was presented in Figure 5. The results presented in Figs. 6-7 show the variation of thermal comfort index, and indoor temperature of test room with and without PV-TW system. Also mitigation of $\mathrm{CO}_{2}$ and energy consumption reduction by PV-TW system was done. Moreover changes occur due to PV-TW system in indoor climatic condition of test room were presented in Figs. 8-10. The detailed discussion of simulation results are given in the subsequent subsections.

\subsection{Thermal comfort of occupants with different PV-TW system.}

Comparative study of building with and without different types of PV-TW system on thermal comfort of occupants were investigated and presented in Figs. 8-10. It was found that maximum thermal comfort indexes reduced by SPV-TW system was $14 \%$ PMV index and 26\% PPD index while DPV-TW system reduces $24 \%$ of PMV and $31 \%$ of PPD index as compared to building without PVTW. DGPV-TW system gives optimal results and reduces $35 \%$ of PMV and 38\% PPD index as compared to normal building. From September to December PMV indexes lies in between $(0<\mathrm{PMV}<1)$ and PPD indexes were less than $20 \%$ in both DPV-TW and DGPV-TW. This indicates that the condition of Occupant's in this set of month lies in between slightly warm and neutral condition and less than $20 \%$ of the occupants were thermally dissatisfied with the building environment.

While for other months, condition of occupants lies in between $(1<\mathrm{PMV}<2)$ and PPD indexes were more than $15 \%$ for building equipped with SPV-TW and DPV-TW. By comparing the thermal comfort indexes of three different types PV-TW system, it was found that ventilated DGPV-TW system provides more insulation towards heat penetration. So the amount of heat penetrated inside the building and at the back portion of the PV panel gets reduced. Beside these months, i.e. January, February and July, less than $20 \%$ occupants feel thermal discomfort which lies in the recommend range of ASHARE [20]. Other researchers also found that more comfortable conditions were provided by building equipped with high insulating glazing $[23,24]$. 


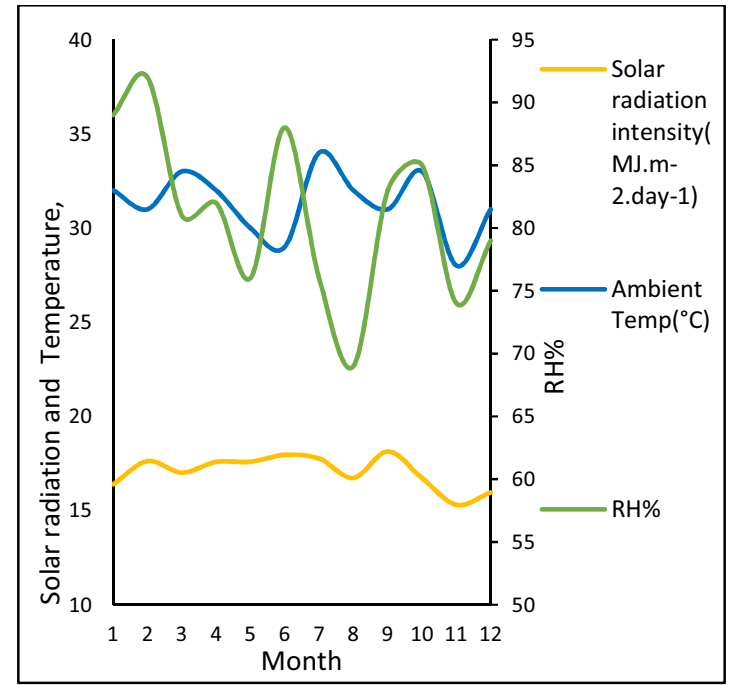

Figure 5. Outdoor climatic condition of test room.

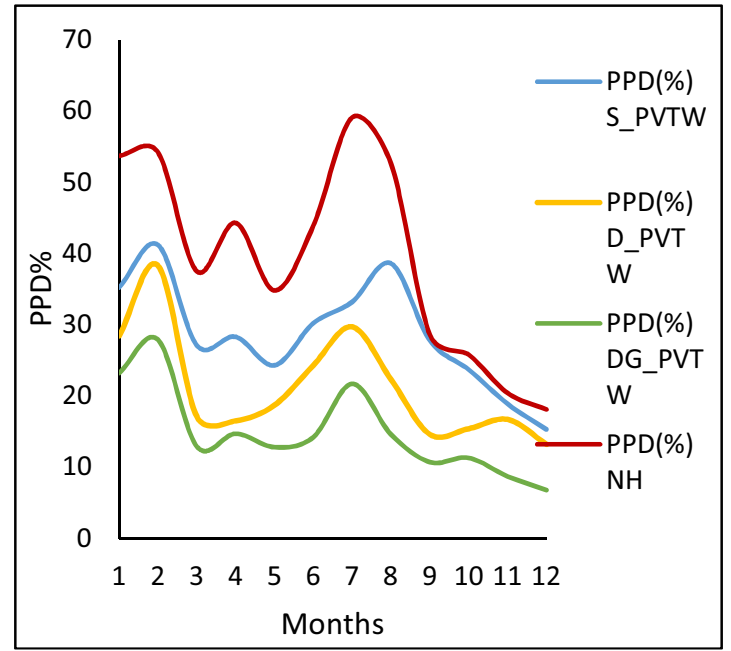

Figure 6. Variation of PPD\% of building equipped with and without different type of PV-TW with months.

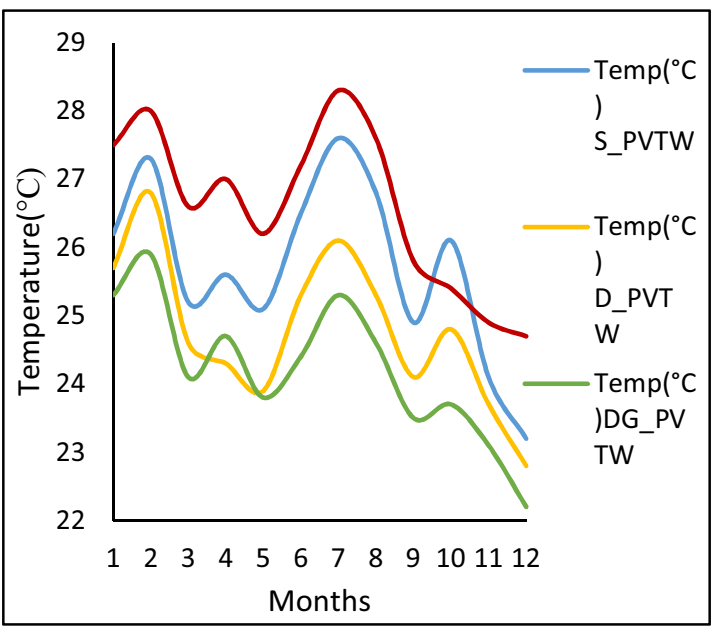

Figure 7. Variation of Indoor temperature of building equipped with and without different type of PV-TW with months

\subsection{Energy consumption and mitigation of $\mathrm{CO}_{2}$ emission.}

Effect of thermal comfort on energy consumption and $\mathrm{CO}_{2}$ emission of building integrated with and without different types of PV-TW was examined. It was pointed out that when the PPD index decreases from $26 \%$ to $38 \%$ as system was changed from SPV-TW to DGPV-TW, energy consumption of building also decreases from 47.5 $\mathrm{kWh}$ to $54.6 \mathrm{kWh}$ per month as compared to normal buildings. Since energy consumption is proportional to $\mathrm{CO}_{2}$ emission and about $0.98 \mathrm{~kg}$ of $\mathrm{CO}_{2}$ is emitted for 1 $\mathrm{kWh}$ [25] of electricity production, $\mathrm{CO}_{2}$ emission also decreases from $33.7 \mathrm{~kg}$ to $38.3 \mathrm{~kg}$. By comparing the energy consumption of building assisted with different type of PV-TW and normal buildings, it was found that more than $50 \%$ of energy consumption and $\mathrm{CO}_{2}$ emission was reduced by implementing DGPV-TW. DGPV-TW provides significant thermal comfort and reduction in energy consumption and $\mathrm{CO}_{2}$ emission as compared to other types of PV-TW. Likewise, for rest of the months with the exception of January, February and July, DGPVTW provides more thermal comfort, reduction in energy consumption and $\mathrm{CO}_{2}$ emission. Other researchers also found that annual energy demand reduces significantly by using energy efficient glazing [24, 26].

\subsection{Indoor climate condition of test room for different PV-TW system.}

The effects of three different types of PV-TW system on indoor climatic condition of the test room was investigated and presented in Figs. 8, 9 and 10, respectively. Three days simulation data for each type of PV-TW was presented in order to reduce haziness in graph. It was found that the room temperature first decrease and then increases in the presence of sunlight and finally decreases in the night time for all three types of PV-TW system. This behavior is due to heat wave propagation from outside surface (i.e. PV panel) to the inner surface of the wall which requires time or called as time lag [7]. Simulated results demonstrated in Figure 8 shows that SPV-TW reduces $0.8-1.4^{\circ} \mathrm{C}$ indoor temperature while DPV-TW system as presented in Figure 9, can reduce $1.2-3.1^{\circ} \mathrm{C}$ indoor temperature. Among all the three cases, DGPV-TW system shows highest reduction in indoor temperature of $2.6-4.8^{\circ} \mathrm{C}$ as presented in Figure 10. Thus DGPV-TW system provides more insulation towards heat penetration, so the amount of heat penetrated inside the building get reduced. By comparing our results with $\mathrm{Ji}$ et.al [27] experimental results it was found that for Hefei, China climate the temperature difference between the room with and without PV-TW reaches maximum up to $12.3^{\circ} \mathrm{C}$ [27] but for Ipoh, Malaysia climate maximum temperature difference between the room with and without PV-TW reaches up to $4.8^{\circ} \mathrm{C}$ for DGPV-TW case. Other researchers also shown that ventilated PV-TW has a significant effect on room temperature of the building and reduces $33 \%-50 \%$ cooling load of building as compared to normal buildings $[28,10]$. 


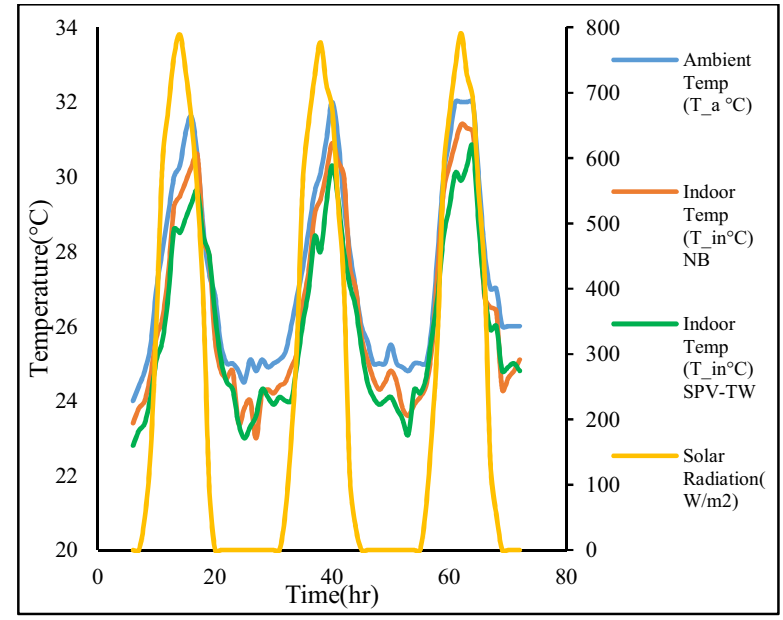

Figure 8. Indoor climatic condition of test room equipped with and without SPV-TW from January 1-3, 2015.

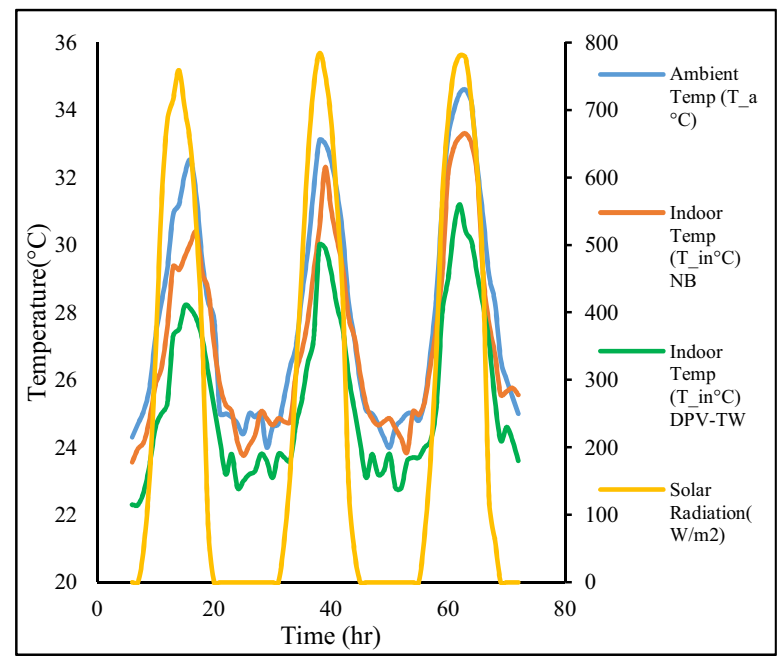

Figure 9. Indoor climatic condition of test room equipped with and without DPV-TW from January 7-9, 2015

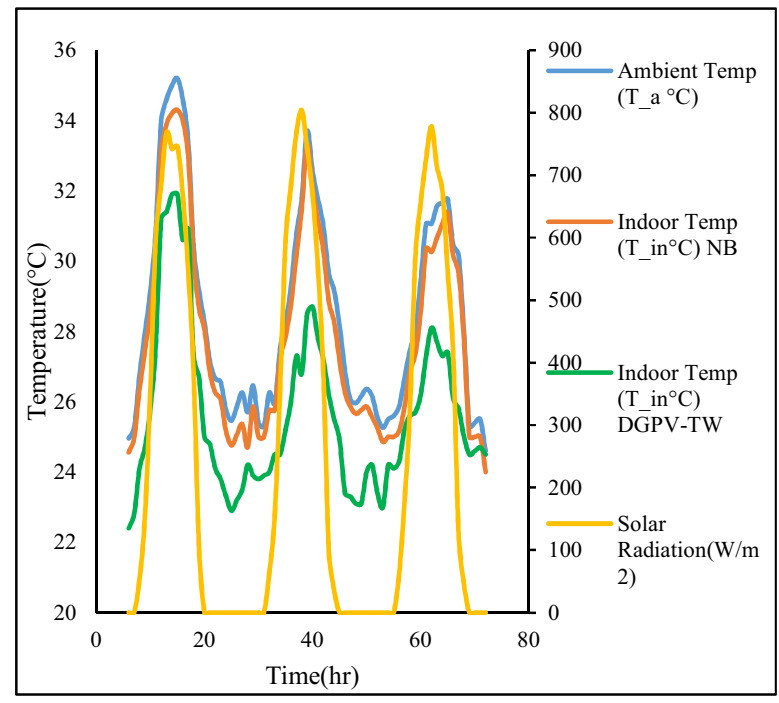

Figure 10. Indoor climatic condition of test room equipped with and without DGPV-TW from January 10-12, 2015.
By comparing our results with J. Peng et al. [13] results as presented in Figure 11, it can be inferred that room coupled with DGPV-TW system shows maximum heat gain reduction.

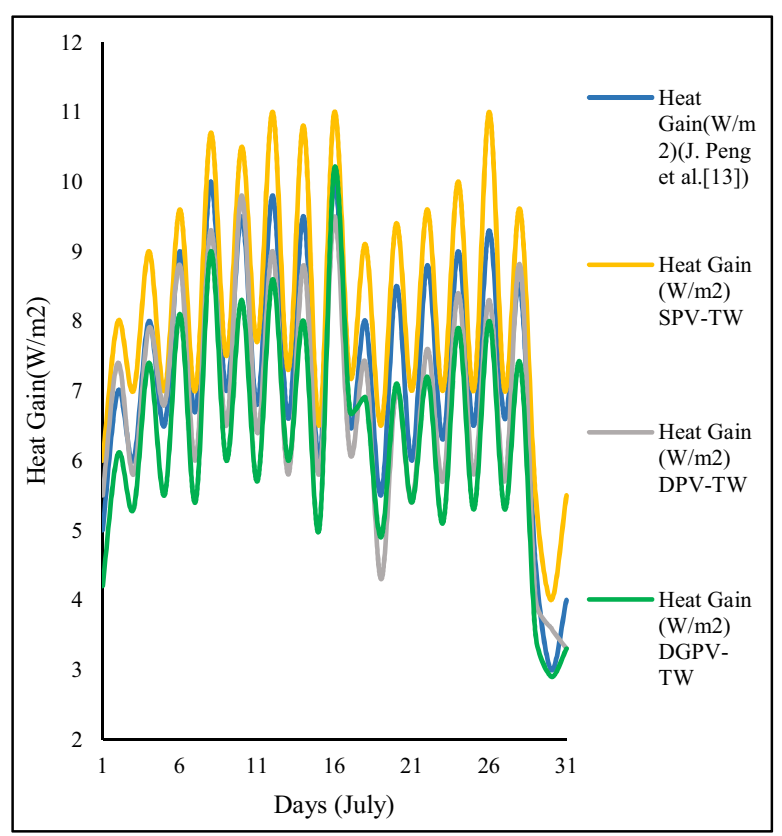

Figure 11. Heat gain comparison of different type of PV-TW installed the building with previous study for the July month.

\section{Conclusions}

Simulation study was carried out to examine the effect of different types of PV-TW on thermal comfort, energy consumption and $\mathrm{CO}_{2}$ emission. It was found that factors like solar radiation, air temperature, humidity, wind, and PV-TW have a high impact on indoor climatic condition of the building. Thermal comfort indexes (PMV and PPD) decrease as system was changed from SPV-TW to DGPV-TW. Occupants feel more comfort when DGPVTW systems was implemented. As energy consumption and $\mathrm{CO}_{2}$ emission of the building are proportional to thermal comfort of occupants, implementation of any type PV-TW system discussed above reduces both factors. Maximum reduction of energy consumption i.e. $54.6 \mathrm{kWh}$ and $\mathrm{CO}_{2}$ emission i.e. $38.6 \mathrm{~kg}$ was achieved in DGPV-TW systems and thus among all three types of PV-TW systems DGPV-TW system is more suitable for Malaysian weather conditions.

\section{Acknowledgments}

The authors of current work wish to thank Universiti Teknologi PETRONAS for their facilities and financial support.

\section{References}

1. IPCC. Climate Change New York, NY, USA (2001). 
2. F. Oldewurtel, A. Parisio, C.N. Jones, D. Gyalistras, M. Gwerder, V. Stauch, B. Lehmann, M. Morari, M, Energy Build. 45, 15-27(2012).

3. ISO 7730, Ergonomics of the thermal environment (2005).

4. T. Schuetze, Energies 6, 2982-3001(2013).

5. J. Yudelson, N. Society Publ (2007).

6. B. Kundakci Koyunbaba, Z. Yilmaz, Renew. Energy 45, 111-118(2012).

7. J.A. Duffie, W.A. Beckman, $4^{\text {th }}$ Ed. (2013)

8. $\tilde{A}$, J. J, Y. Hua, H. Wei, P. Gang, L. Jianping, J. Bin, Build. Envi. 42, 1544-1552(2007).

9. W. Sun, J. Ji, C. Luo, W. He, Appl. Energy 88, 224-231(2011).

10. H. Yang, J. Burnett, J. Ji, Energy Build 285290(2000).

11. W. He, J. Ji, HVAC 33, 8-11(2003) [in Chinese].

12. H. Yang, J. Ji, Acta Energiae Solaris Sinica, 20(3), 270-3(1999).

13. J. Peng, L. Lu, H. Yang, J. Han, Appl. Energy 112, 646-656(2013).

14. W. Liao, S. Xu, Energy 83,267-275(2015).

15. Solar Energy Laboratory Univ. of WisconsinMadison, TRNSYS 17, (2009).

16. J. Jie, Y. Hua, P. Gang, L. Jianping, Appl. Therm. Eng 27, 1507-1515(2007).

17. EN 15251 (2006)

18. J.F. Kreider, P. Curtiss, A, Rabl, Desgn. Eff., McGraw-Hill, (2002).

19. http://www.bnm.gov.my/microsites/monetary/index .htm.

20. ASHRAE Standard 62-99, (1999).

21. S.M. Shafie, H.H. Masjuki, T.M.I Mahlia. Energy 70,401-10(2014).

22. A. Chel, G.N. Tiwari,A. Chandra. Energy Build 41,1172-80(2009).

23. A. Tzempelikos, M. Bessoudo, A.K. Athienitis, R. Zmeureanu, Build. Environ, 45, 2517-2525(2010).

24. C. Buratti, E. Moretti, E. Belloni, F. Cotana, Build. Environ. 59, 482-491(2013).

25. M.E. Watt, A.J. Johnson, M. Ellis, H.R. Outhred, Prog. Photovoltaics 6,127-136(1998).

26. K. Irshad, K. Habib, N. Thirumalaiswamy, Eng. Proc. 50, 71-78(2014).

27. J. Jie, Y. Hua,P. Gang, J. Bin, H. Wei, Build. Environ. 42, 3529-3539(2007).

28. C. Peng, Y. Huang, Z. Wu, Z, Energy Build. 43, 3592-3598(2011). 